\title{
Esthetic restoration using digital techniques in a patient with cleft lip and palate
}

\author{
Lydia Park', Sangwon Park², Hyun-Pil Lim², Kwidug Yun², Chan Park³ and Woohyung Jang ${ }^{4 *}$ \\ ${ }^{1}$ Resident, Department of Prosthodontics, School of Dentistry, Chonnam National University, Gwangju, Republic of Korea \\ ${ }^{2}$ Professor, Department of Prosthodontics, School of Dentistry, Chonnam National University, Gwangju, Republic of Korea \\ ${ }^{3}$ Assistant Professor, Department of Prosthodontics, School of Dentistry, Chonnam National University, Gwangju, Republic of Korea \\ ${ }^{4}$ Fellow, Department of Prosthodontics, School of Dentistry, Chonnam National University, Gwangju, Republic of Korea
}

The use of prosthetic restorations in patients with cleft lip and palate is limited due to the presence of an imbalanced facial harmony, a narrowing of the nose, and a scar in the upper lip. Additionally, the alignment of the anterior teeth is affected due to the constriction of the maxillary arch. To overcome these limitations, a prosthetic design was implemented via communications between the patient and the dental technicians. Digital techniques were used to diagnose and design the prosthesis via three-dimensional (3D) facial scanning (Bellus 3D facial scan app) and integration of the intraoral scanning data. The patient was satisfied with the esthetic and functional outcome of the treatment.

Key Words: Cleft lip; Cleft palate; Dental implant; Dental restoration, permanent; Digital technology

(c) This is an open-access article distributed under the terms of the Creative Commons Attribution Non-Commercial License (http://creativecommons.org/licenses/by-nc/4.0) which permits unrestricted noncommercial use, distribution, and reproduction in any medium, provided the original work is properly cited.

\section{Introduction}

치과에서 디지털 기술은 최근 몇 년 동안 구강 스캐너 및 소프 트웨어 프로그램과 같은 기술의 발전으로 인해 증가하고 있으 며, 이는 임상의와 치과 기공사 간의 의사 소통을 향상시키고 심 미적인 보철 수복에 기여했다[1].

구강스캐너(intra oral scanner), computer-aided design (CAD) 소프트웨어 및 computer-aided manufacturing (CAM) 기술의 개발 및 통합을 통해 진단 및 치료 계획을 위해 디지털 워크플로를 사용할 수 있다[2-4].

또한, 치과 수복물의 디자인 단계에서 심미적 분석을 위해 안 면 스캔을 적용하는 개념이 보철학에 도입되었다. 3차원(three- dimensional, 3D) 안면 스캐너는 환자의 안모를 3차원 시각화 하여 보철 수복을 위한 진단 및 치료에 사용할 수 있다[5-7]. 안 면 스캐너를 이용하여 채득한 안면 스캔과 구강 스캔의 중첩을 통해 심미적인 수복이 어려운 환자에서 환자의 안모와 조화되 는 보철물을 제작할 수 있다.

구순구개열 환자의 상악 전치부 고정성 수복에서는 심미적 수복에 한계가 존재한다. 상악 전치부의 소실 및 상악궁의 협착 으로 인해 기존 치아와 조화로운 보철 수복이 어렵다[8]. 또한, 술 후 상순에 형성된 반흔 및 코의 형태 이상으로 안모와 조화되 고 안면 정중부선에 맞춘 보철 수복이 어려워 심미적인 수복이 어렵다. 이러한 한계를 가지고 있는 환자에서 3D 안면 스캔을 채득하여 구내 스캔 파일과 중첩 후 진단 및 치료 계획의 시각화

Received July 28, 2021; Revised [1] August 14, 2021; [2] August 24, 2021; [3] September 5, 2021; Accepted September 7, 2021

*Corresponding author: Woohyung Jang, Department of Prosthodontics, School of Dentistry, Chonnam National University, 309 Pilmun-daero, Dong-gu, Gwangju 61452, Republic of Korea.

Tel: +82-62-530-5638, Fax: +82-62-530-5639, E-mail: whjang1989@hanmail.net 

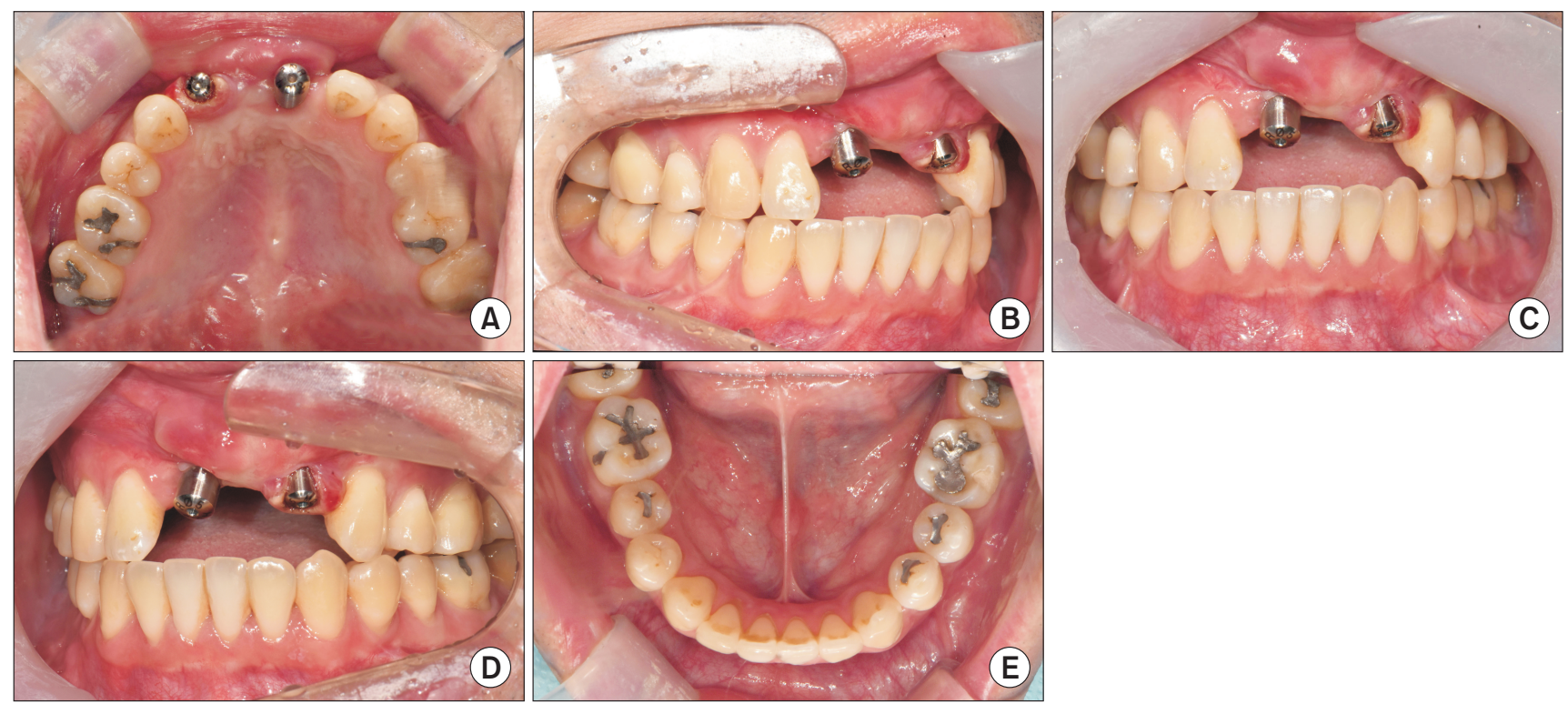

Fig. 1. Intraoral examination before the treatment. (A) Maxillary occlusal view, (B) right lateral view, (C) frontal view, (D) left lateral view, (E) mandibular occlusal view.

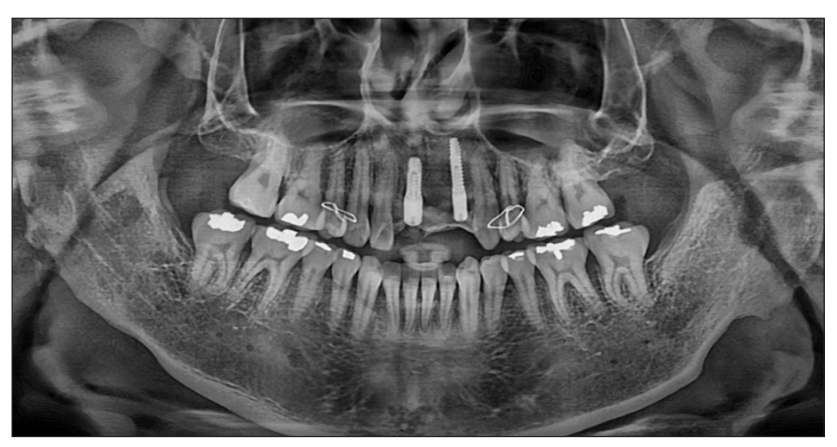

Fig. 2. Taking initial panoramic radiograph after \#11, 22 implant installation and bone graft.

를 통해 심미적으로 보철 수복이 가능하다.

본 증례는 구순구개열로 인한 수술 및 교정치료 후 상악 전치 부 상실에 대해 임플란트 고정성 보철 수복을 시행한 경우로, 디 지털 기법인 $3 \mathrm{D}$ 안면 스캔 및 구내 스캔의 중첩을 활용하여 심 미적인 보철 수복을 시행했다. 보철 제작 과정에서 구강스캔, 안 면스캔, 기공용 스캔 등과 함께 적층가공 및 절삭가공의 다양한 디지털 기술을 활용하였고, 만족할 만한 결과를 보였기에 이를 보고하는 바이다.

\section{Case Description}

본 증례의 환자는 좌측 편측성 구순구개열인 25세 남자 환자 로 상악 전치부 상실에 대한 보철수복을 위해 내원하였다. 본 연

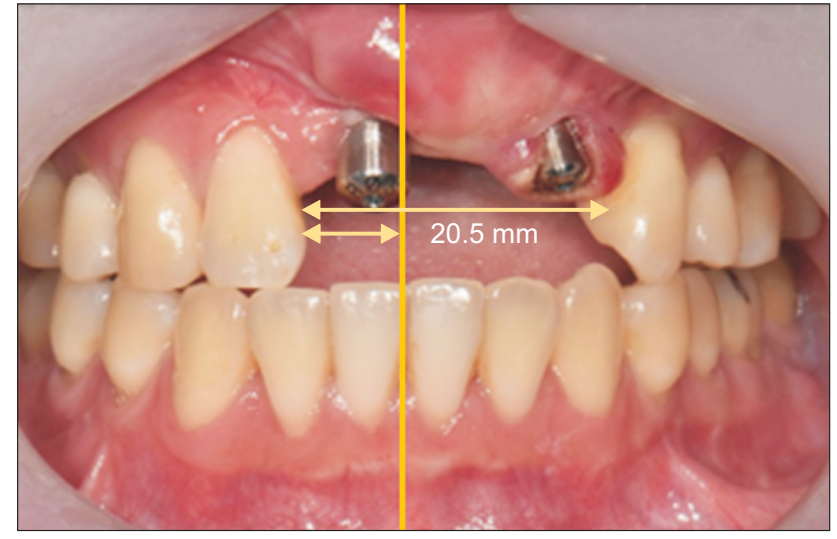

Fig. 3. As a result of analyzing the restoration space, it was found that the space to be restored is $20.5 \mathrm{~mm}$, and it is necessary to properly distribute the restoration space for the esthetic restoration because it is non-esthetic if the midline of the maxilla is aligned with the midline of the mandible during prosthetic restoration.

구에 대해 환자에게 설명하였으며, 서면 동의를 받아 진행하였 다. 일차 구순구개열 수술 후 해당 부위 골이식을 시행하였으며, 2008년부터 2017년까지 교정치료를 진행하였다. 추후 골 이식 및 \#11, 22 임플란트 식립하였으며 이를 지대치로 하는 3-unit 상악 전치부 보철 수복을 위해 보철과를 내원하였다(Fig. 1, 2).

젊은 남자 환자로 내원 시 심미적인 보철 수복을 원하는 상태 였다. 이를 위해 먼저 심미분석을 시행하였다. 첫 번째로 수복 공간을 분석한 결과, 현재 수복해야 하는 공간은 $20.5 \mathrm{~mm}$ 로 보 철 수복 시 하악 정중선에 상악의 정중선을 일치시킬 경우 비심 
미적이기 때문에 심미적 보철 수복을 위해 적절한 보철물 수복 공간 분배가 필요함을 알 수 있었다(Fig. 3). 그리고 환자의 안모 측면의 분석 결과 비순각(nasolabial angle)은 92도로 평균치였 으나 상악 전치부 상실로 concave한 안모형태를 띤다. 코의 끝 과 턱의 전방부를 연결하는 가상선인 Rickett's E-plane을 기준 으로 상순은 약 $5 \mathrm{~mm}$ 후퇴, 하순은 약 $1 \mathrm{~mm}$ 전돌되어 상순에 비하여 하순이 더 돌출되어 보이는 것을 관찰할 수 있다(Fig. 4). 마지막으로 치아-안면 구도에서 환자의 안면 정중선은 우측으 로 기울어졌고 구순구개열 및 파열부 수술로 인해 코의 협착, 인 중, 입술의 큐피드 활의 비대칭성으로 안면 정중선이 명확하지
않았다. 이로 인해 안모와 조화로운 치열 정중선의 설정이 어려 움을 관찰할 수 있었다(Fig. 5).

위와 같은 분석을 토대로 본 환자의 치료적 문제 목록을 정리 해보면 첫째로 수술 후 상순에 형성된 반흔 및 코의 변형으로 인 한 치열 정중선 설정 및 안모와 조화된 보철 수복에 한계가 있 다. 두 번째로 심미적인 비율에 맞는 보철 수복의 어려움이 있 다. 이러한 문제를 해결하기 위해 스마트폰을 이용하여 쉽고 빠 르게 $3 \mathrm{D}$ 디지털 안모 스캔을 채득하고, 구내 스캔과 중첩하여 안모와 조화되는 보철 제작을 위해 디지털 진단 납형 형성부터 시작하여 $\mathrm{CAD} / \mathrm{CAM}$ 보철 제작까지 시행하였다.
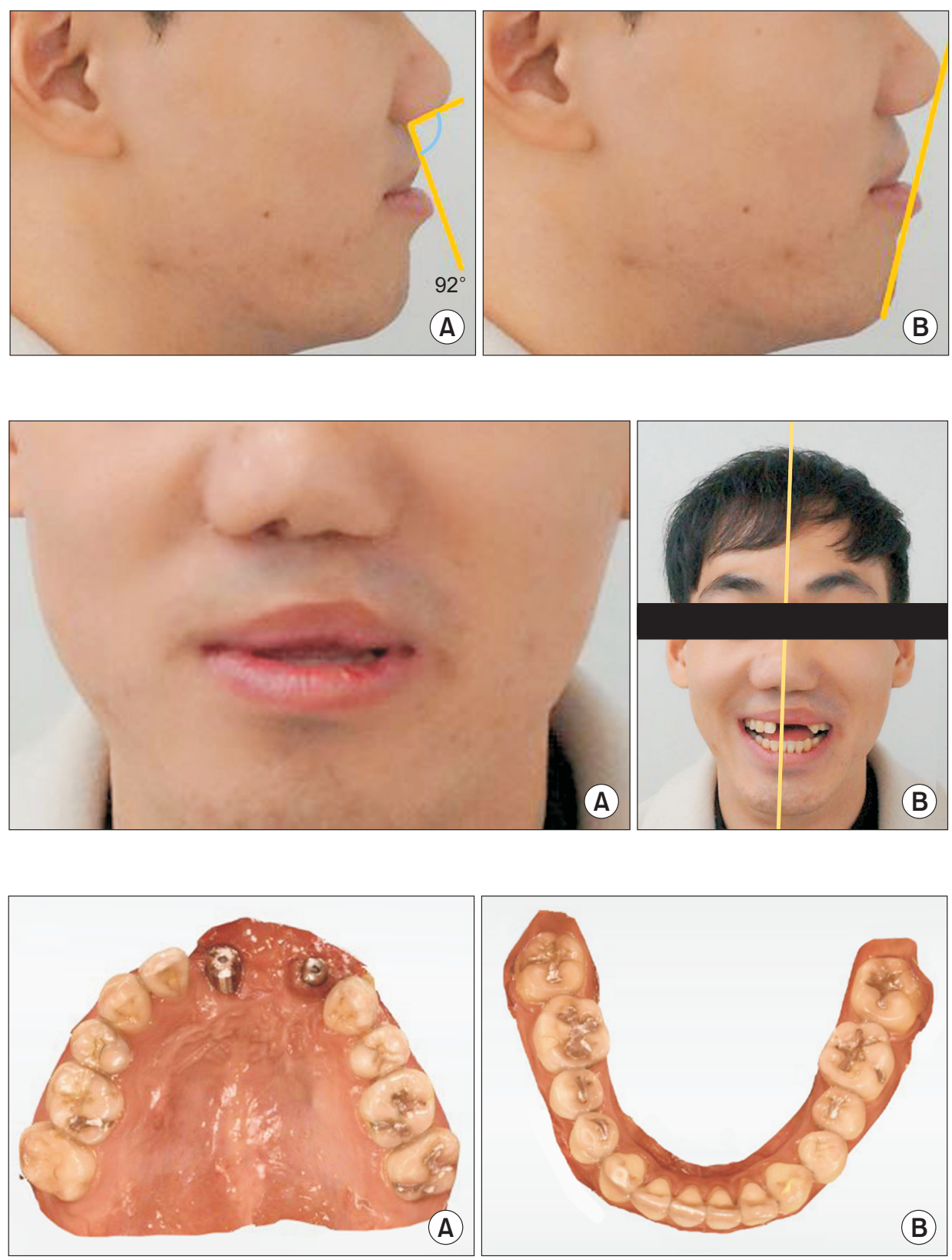

Fig. 4. (A) The nasolabial angle is an average of 92 degrees but it has a concave face shape due to the loss of the maxillary anterior teeth. (B) Based on Rickett's E-plane, which is an imaginary line connecting the tip of the nose and the anterior part of the chin, the upper lip retracts about $5 \mathrm{~mm}$ and the lower lip protrudes about $1 \mathrm{~mm}$, so it can be observed that the lower lip is more protruding than the upper lip.

Fig. 5. (A) Asymmetry of the cupid's bow on the lips due to cleft lip and rupture surgery. (B) The patient's facial midline is tilted to the right, and the facial midline is not clear due to stenosis of the nose, pharynx. And it is difficult in setting the midline of the dentition in harmony with the face.

Fig. 6. In order to perform digital diagnostic wax-up before prosthetic restoration, intraoral scans are first obtained using an intraoral scanner (CEREC primescan; Dentsply sirona, Bensheim, Germany). (A) Intraoral scan of maxilla. (B) Intraoral scan of mandible. 
보철 수복 전 디지털 진단 납형 형성을 시행하기 위해 먼저 구강스캐너(CEREC primescan; Dentsply sirona, Bensheim, Germany)를 이용하여 구내 스캔을 채득하였다(Fig. 6).

안모와 조화되는 보철 제작을 위해 안면스캔 어플리케이션 (Bellus3D dental pro application, Bellus3D; Bellus3D Inc., Cambell, CA, USA)을 실행하여 스마트폰에 내장된 카메라로 스마일 상태에서 안면스캔 파일을 채득하였다(Fig. 7). 안면스캔 은 10초 이내로 짧은 시간에 채득 되었으며 환자가 카메라를 응 시하고 고개를 좌우로 천천히 돌려 채득하였다. 구내 스캔과 중 첩을 위해 안면 스캔의 입술 라인을 지정한 후 안면 스캔의 치 아와 구강 내 스캔의 치아를 맞추어 중첩하였다(Fig. 8). 중첩 후 동공간선 및 캠퍼스라인, 교합 평면을 지정하는 가이드선을 안 면 스캔 및 구내 스캔에 맞추어 조정 시행하였다(Fig. 9).

CAD 프로그램(Dental designer; 3Shape, Copenhagen, Denmark)을 이용하여 진단 납형 형성을 진행하기 위해 구내 스 캔 파일, 안면 스캔, 조정한 가이드선을 업로드하였다. 가상의 교합기를 사용하여 캠퍼스 라인에 평행하게 가상 교합 시행하 였다(Fig. 10).

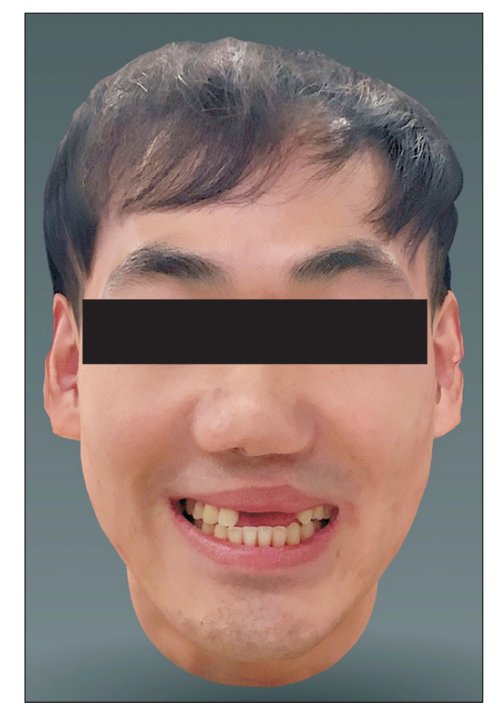

Fig. 7. Facial scan with smile in Bellus3D dental pro application (Bellus 3D; Bellus3D Inc., Cambell, CA, USA) and I-phone camera.
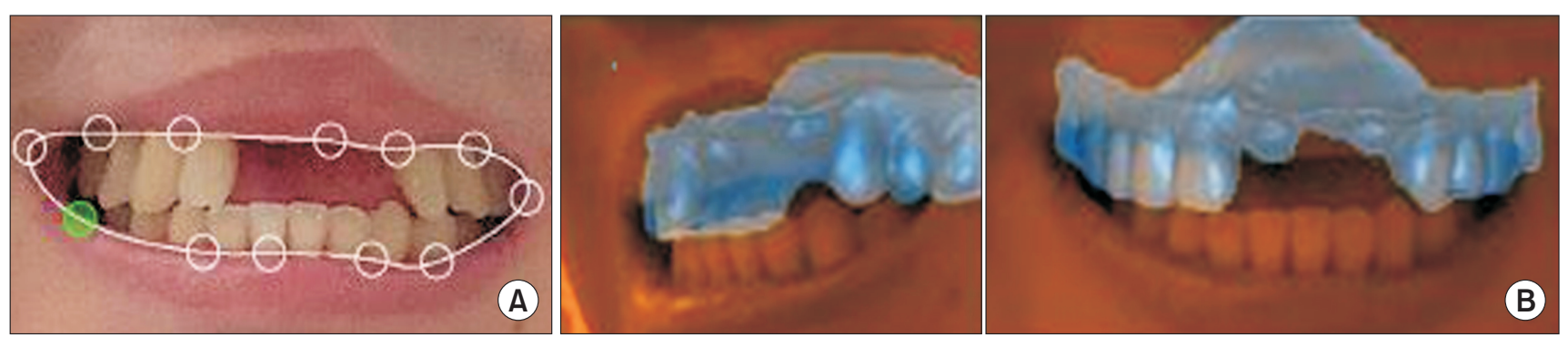

Fig. 8. Design the lip line of the facial scan to overlap with the intraoral scan using Bellus 3D application (Bellus 3D; Bellus3D Inc., Cambell, CA, USA). (A) Lip line adjustment. (B) Adjustment of intraoral scan on facial scan.
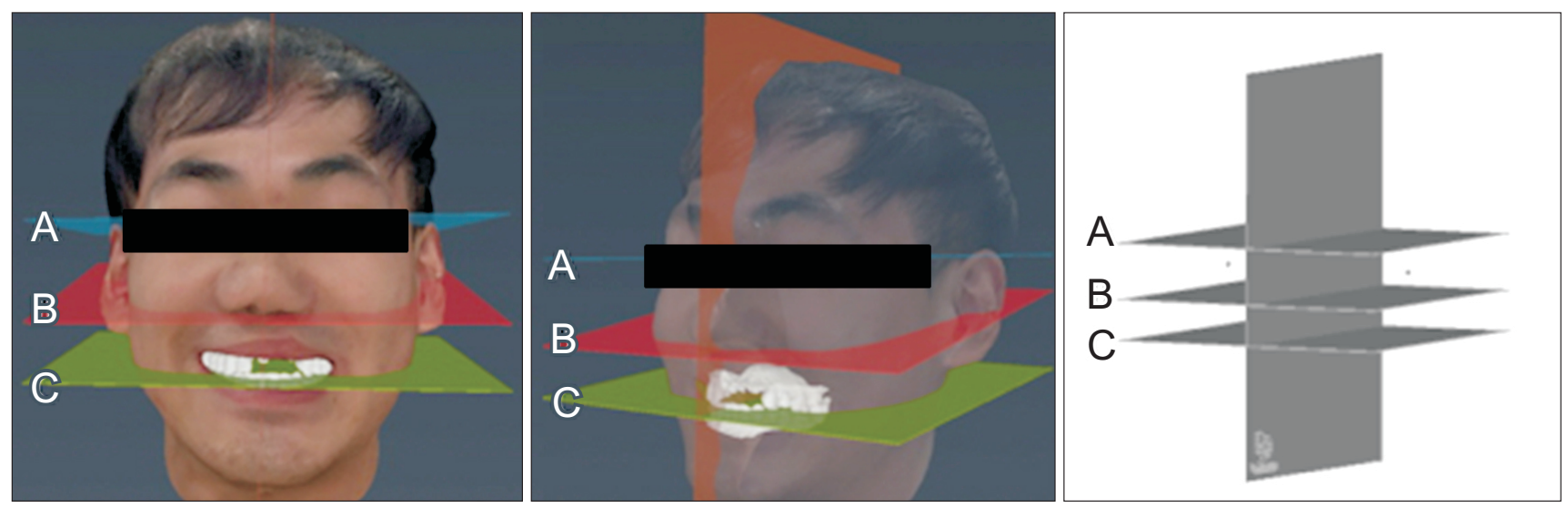

Fig. 9. After facial scan and intraoral scan overlapping, the pupil line, campus line, and guide line designating the occlusal plane are adjusted in 3D application (Bellus 3D; Bellus3D Inc., Cambell, CA, USA) for digital mounting in CAD program. (A) Interpupillary line. (B) Camper's line. (C) Occlusal plane. CAD, computer-aided design. 

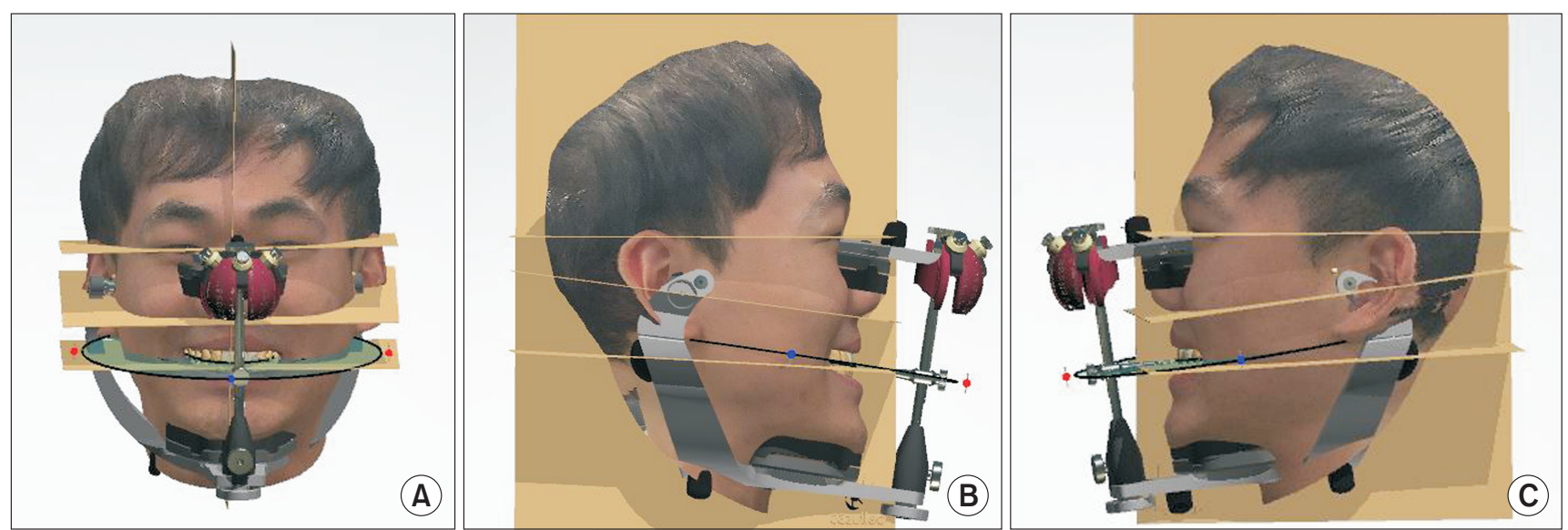

Fig. 10. Using a CAD program (Dental designer; 3Shape, Copenhagen, Denmark), intraoral scan files, facial scans, and adjusted guide lines are uploaded to proceed with the diagnostic wax up. Virtual occlusion is performed parallel to the campus line using a digital articulator. (A) Frontal view. (B) Right view. (C) Left view. CAD, computer-aided design.
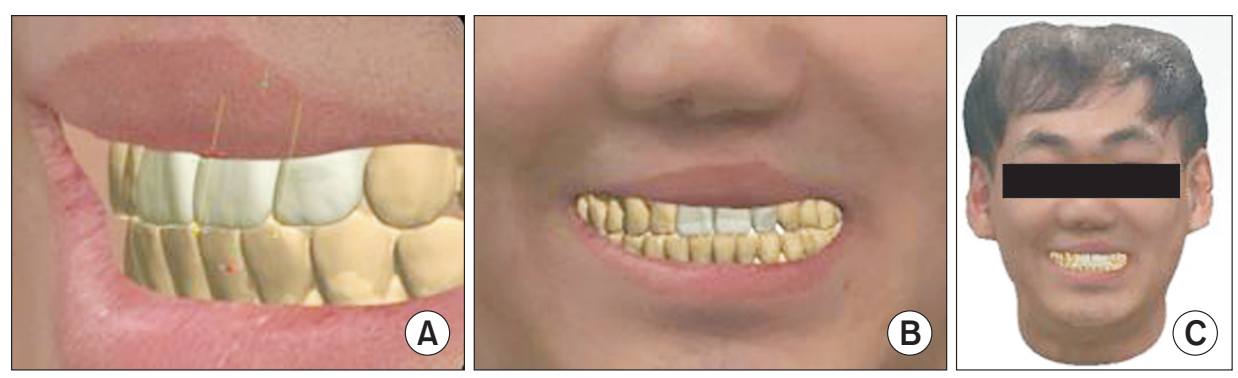

Fig. 11. Digital diagnostic wax-up in 3 shape CAD/CAM software program (Dental designer; 3Shape, Copenhagen, Denmark). (A) Wax-up design and adjustment with facial scan. (B) Check the digital wax-up design with lip shape. (C) Check the wax-up with facial scan. CAD/CAM, computeraided design/manufacturing.
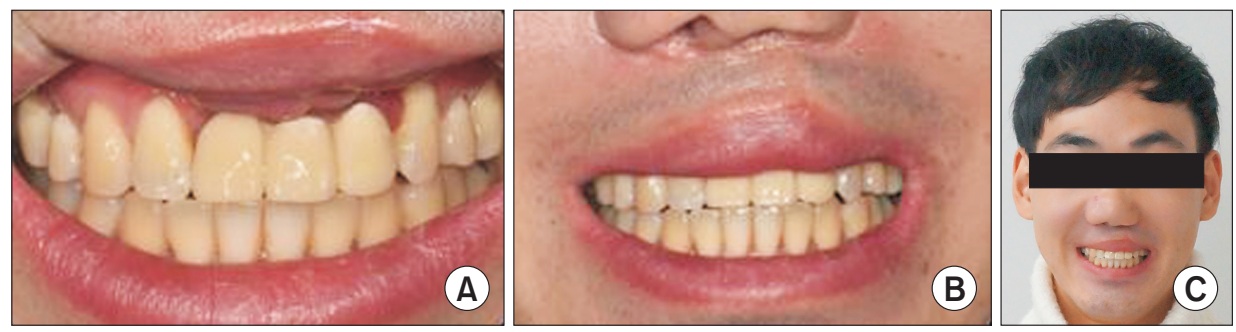

Fig. 12. (A) Resin provisional bridge restoration. (B) Provisional prosthesis with lip shape. (C) Provisional prosthesis with facial appearance.

환자의 안면스캔 파일, 구내 스캔, 가상 교합을 모두 중첩한 상태에서 가상의 납형 형성을 시행하였다. 안면 정중선이 오른 쪽으로 기울었으며, 하악의 잔존치 정중선과 일치하지 않아 상 악의 새로운 정중선 설정이 필요하였다. 하악의 정중선과 일치 하지는 않지만 \#11, 21, 22 보철 수복 너비의 심미적인 분배 및 \#11, 21 대칭적으로 왁스업을 시행하였다. 보철을 위한 인상 채 득 날 이를 환자에게 보여주며 환자의 요구 사항을 반영하여 납 형 형성 수정 진행하였다. 환자분 하악 잔존치의 정중선에 맞추 어 제작 원했고, 둥근 형태보다는 각진 형태의 치아 모양을 원해 이를 반영하여 납형 형성 수정하였다(Fig. 11).

비가역성 하이드로콜로이드 인상재(Honigum light bod- ied consistency and Heavy consistency; DMG, Hamburg, Germany)로 인상채득하여 모형을 제작하였으며, 맞춤형 지대 주 및 임시치아를 제작하기로 하고, 납형 형성한 보철 디자인 을 임시보철물 디자인에 반영하였다. 티타늄 맞춤형 지대주(US Pre-milled Abutment; Osstem, Seoul, Korea) 및 Polymethyl methacrylate 재질의 임시 보철물을 제작하였다(Fig. 12).

약 1 개월간 임시보철을 사용하면서 보철물의 모양 및 치은 모 양 형성을 관찰하였다. 최종인상을 결정하고 지대주 상태에서 구강스캐너(CEREC primescan; Dentsply sirona)을 사용하여 디지털 인상을 채득하였다(Fig. 13).

$\mathrm{CAD}$ 프로그램(Dental designer; 3Shape)을 이용하여 최종 


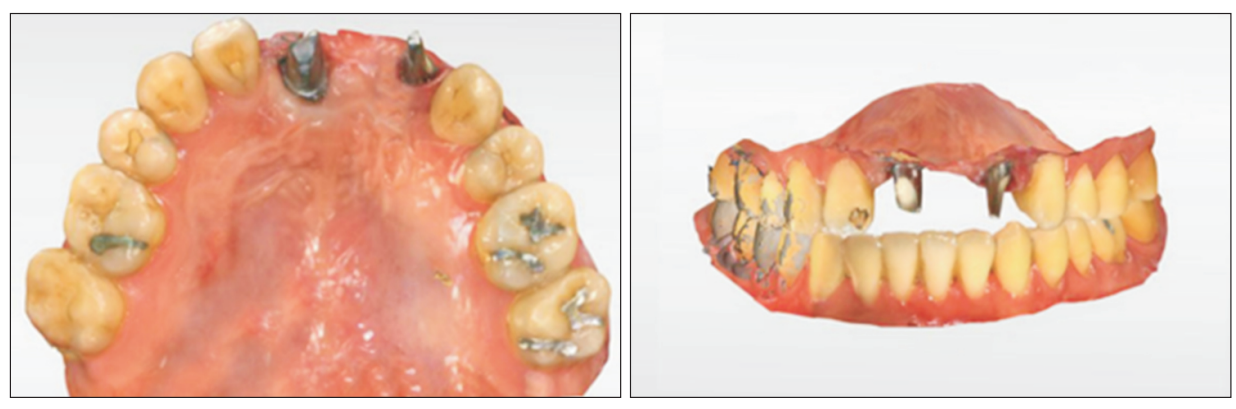

Fig. 13. Final impression in abutment level with intraoral scanner (CEREC primescan; Dentsply sirona, Bensheim, Germany).
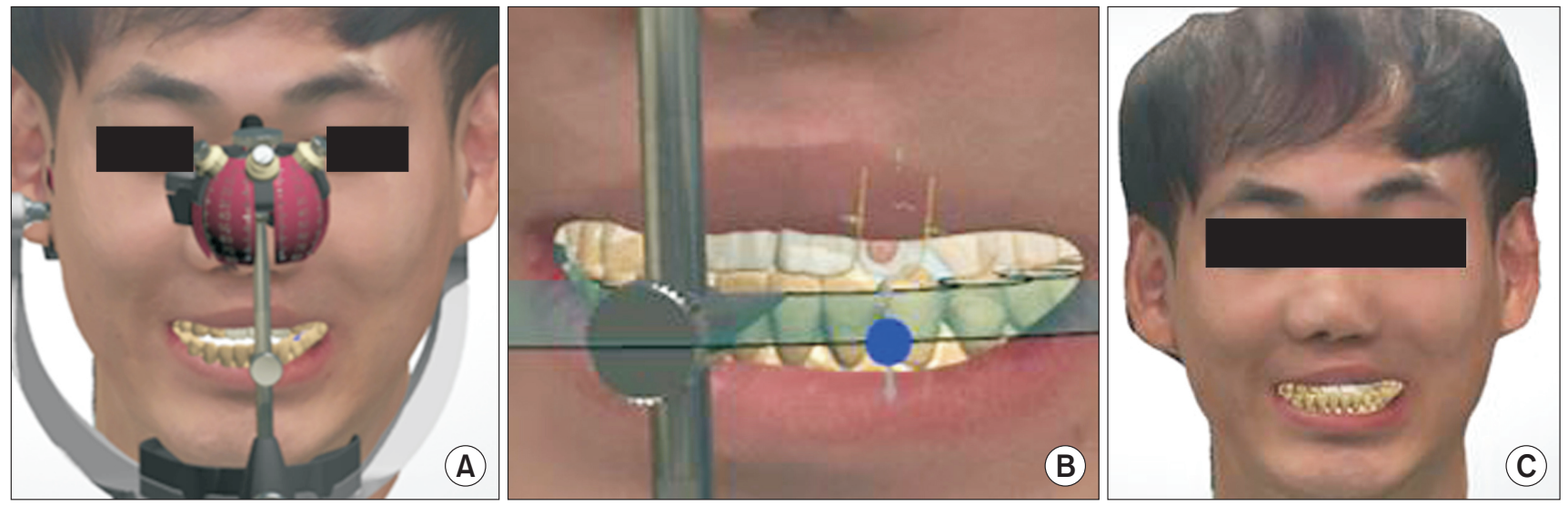

Fig. 14. CAD/CAM design for definitive bridge with facial scan (Dental designer; 3Shape, Copenhagen, Denmark). The patient was satisfied with the appearance of the provisional prosthetic design. (A) Articulator movement to check occlusion. (B) Prosthesis design and adjustment with facial scan. (C) Check the final prosthesis design with facial scan.
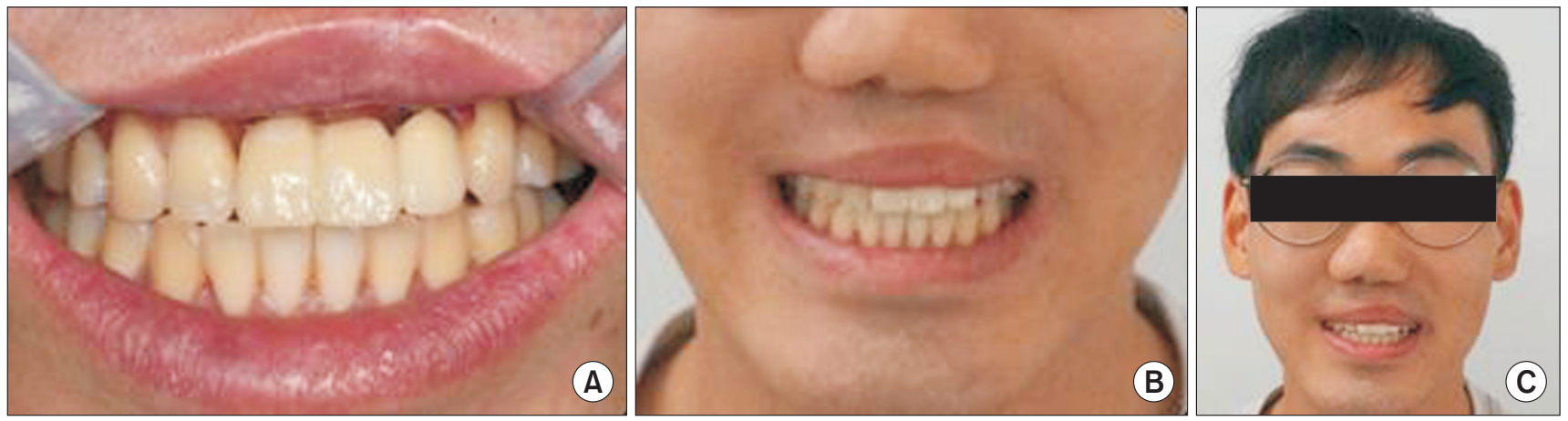

Fig. 15. (A) Definitive monolithic zirconia bridge restoration (Zirmon S; Kuwotech, Gwangju, Korea). (B) With smile line, (C) with facial appearance.

보철을 디자인하기 위해 지대주 인상채득 파일, 안면 스캔, 가이 드선을 업로드하였다. 환자는 현재 임시 보철의 모양에 만족하 여 이를 반영해 최종 보철 디자인을 시행하였다(Fig. 14). 구외 스캔 파일을 통해 하악의 정중선에 맞추어 정중선의 재확인 및 치아 너비 설정을 시행하였으며, 진단 납형 형성과 비교하고 이 를 반영하여 최종 보철 디자인을 시행하였다. 심미성이 강화된 지르코니아 블록(Zirmon S; Kuwotech, Gwangju, Korea)을
이용하여 지르코니아관을 제작 후 장착하였다(Fig. 15).

\section{Disscusion}

본 증례의 환자는 구순구개열 및 수술로 인해 코의 협착, 인 중, 입술의 큐피드 활의 형태 변형으로 상악 전치부 보철 수복 시 정중선 설정의 어려움 및 변형된 안모에 어울리는 보철 수 
복의 어려움이 있었다. 그렇기에 구강스캐너, 3D 안면 스캐너, $\mathrm{CAD}$ 소프트웨어를 이용하여 정중선의 설정 및 안모와 어울리 는 심미수복을 시행하였다. 본 증례 환자의 경우 구순구개열 수 술 및 잦은 골이식을 시행하였고 이에 따라 두 개의 임플란트 식 립을 각각 다른 시기에 진행하여 술전에 최종 보철 디자인을 시 행하지 못했다. 식립된 상태에서 최대한 심미적 결과를 얻기 위 해 디지털 기법을 사용하여 보철 수복을 시행하였다. 그러나 보 다 심미적이고 예지적인 결과를 위해 술전 최종보철물의 디자 인을 기반으로 임플란트 식립을 시행하는 top down 방식의 수 술적 접근이 필요할 것이다.

전치부 보철의 색상과 형태는 인접한 치아 및 안모와 조화를 이루어야 하며 환자의 선호도와 일치해야 한다[9]. 이를 위해 안 모 사진이 주로 이용된다[10]. CAD 소프트웨어(3 Shape Dental System; 3Shape)를 사용하여 구강 외 사진과 구강 내 디지 털 스캔을 통합하는 것이 제안되었다. 그러나 이 방법의 한계는 연조직 프로파일에 대한 정보를 제공할 수 없다는 것이다[11]. 이러한 한계를 극복하기 위해 3D 안면 스캐너를 이용하여 안모 와 조화되는 보철 수복하는 증례가 보고하고 있다[12].

구강스캔과 전통적인 인상 채득 방식으로 제작한 크라운 의 내면적합도와 변연 적합도를 비교한 연구에서 구강스캐너 를 이용한 크라운이 더 나은 결과를 보인다는 결과가 보고되었 다[13]. 본 증례는 구강스캐너(CEREC primescan; Dentsply Sirona)를 사용하여 구강스캔 진행하였으며, 본 증례에서 사용 된 구강스캐너를 고정성 보철물 제작에 활용하는 것은 임상적 으로 한계 내의 오차를 보인다고 할 수 있다. 또한, 디지털 치의 학의 발전으로 핸드폰에 안면스캔 어플리케이션을 간단히 설치 후 10초 이내에 핸드폰 내장 카메라로 안면스캔 파일을 채득할 수 있다. 안면 스캐너를 비교한 논문에서는 본문에서 사용된 안 면 스캐너가 정확도와 해상도가 낮지만 가장 빠르게 스캔을 채 득할 수 있음을 말하고 있다[14]. 환자의 이동 없이 체어에서 간 단하게 채득 후 스마트폰 어플리케이션을 이용하여 구강 스캔 파일을 채득한 안면 스캔 파일과 빠른 시간 내에 중첩할 수 있 다. 중첩 파일은 $\mathrm{CAD}$ program에 간단한 과정으로 업로드하여 진단 납형 형성 및 보철 디자인 시 안모와 조화를 이루는 치아 외형, 배열, 정중선 설정을 보다 용이하게 할 수 있다. 결과적으 로 시각화된 자료를 이용하여 치료 단계마다 환자와 대화하며 환자의 요구사항을 직접 반영할 수 있다. 그뿐만 아니라 수정사 항을 기공사에게 쉽게 전달하였으며 만족스러운 보철 디자인을 시행할 수 있었다. 결론적으로 심미 보철 수복의 진단 및 치료계 획 시 구내 스캔 및 안면 스캔을 중첩하여 활용하여 보다 심미적 인 보철 수복을 시행할 수 있고 술자 및 환자 모두 만족할 만한 치료 결과를 얻을 수 있다.

\section{Conflicts of Interest}

The authors declare that they have no competing interests.

\section{ORCID}

\author{
Lydia Park \\ https://orcid.org/0000-0002-5007-6076 \\ Sangwon Park \\ https://orcid.org/0000-0002-9376-9104 \\ Hyun-Pil Lim \\ https://orcid.org/0000-0001-5586-1404 \\ Kwidug Yun \\ https://orcid.org/0000-0002-2965-3967 \\ Chan Park \\ https://orcid.org/0000-0001-5729-5127 \\ Woohyung Jang \\ https://orcid.org/0000-0001-8077-6877
}

\section{References}

1. Joda T, Zarone F, Ferrari M. The complete digital workflow in fixed prosthodontics: a systematic review. BMC Oral Health 2017:17:124. doi: 10.1186/s12903-017-0415-0.

2. Revilla-León M, Sánchez-Rubio JL, Besné-Torre A, Özcan M. A report on a diagnostic digital workflow for esthetic dental rehabilitation using additive manufacturing technologies. Int J Esthet Dent 2018;13:184-196.

3. Revilla-León M, Besné-Torre A, Sánchez-Rubio JL, Fábrega JJ, Özcan M. Digital tools and 3D printing technologies integrated into the workflow of restorative treatment: a clinical report. J Prosthet Dent 2019;121:3-8. doi: 10.1016/ j.prosdent.2018.02.020.

4. Revilla-León M, Fountain J, Piedra Cascón W, Özcan M, Zandinejad A. Workflow description of additively manufactured clear silicone indexes for injected provisional restorations: a novel technique. J Esthet Restor Dent 2019;31:213221. doi: 10.1111/jerd.12464.

5. Rufenacht CR. Fundamentals of esthetics. Chicago: Quintessence; 1990;205-241.

6. Spear FM, Kokich VG. A multidisciplinary approach to esthetic dentistry. Dent Clin North Am 2007;51:487-505, x-xi. doi: 10.1016/j.cden.2006.12.007.

7. Ackerman MB, Ackerman JL. Smile analysis and design in the digital era. J Clin Orthod 2002;36:221-236.

8. Acar O, Kaya B, Saka M, Yuzugullu B. Prosthodontic rehabilitation of cleft lip and palate patients using conventional methods: a case series. Int J Prosthodont Restor Dent 
2013;3:120-124. doi: 10.5005/jp-journals-10019-1090.

9. Schuyler $\mathrm{CH}$. The function and importance of incisal guidance in oral rehabilitation. 1963. J Prosthet Dent 2001;86:219-232. doi: 10.1067/mpr.2001.118493.

10. Shin SJ, Noh KT, Kwon KR, Kim HS. Use of digital smile design in esthetic restoration in anterior teeth: a case report. J Korean Acad Prosthodont 2017;55:164-170. doi: 10.4047/jkap.2017.55.2.164.

11. Hassan B, Gimenez Gonzalez B, Tahmaseb A, Greven M, Wismeijer D. A digital approach integrating facial scanning in a CAD-CAM workflow for complete-mouth implantsupported rehabilitation of patients with edentulism: a pilot clinical study. J Prosthet Dent 2017;117:486-492. doi: 10.1016/j.prosdent.2016.07.033.
12. Park JM, Oh KC, Shim JS. Integration of intraoral digital scans with a 3D facial scan for anterior tooth rehabilitation. J Prosthet Dent 2019;121:394-397. doi: 10.1016/ j.prosdent.2018.03.018.

13. Haddadi Y, Bahrami G, Isidor F. Accuracy of crowns based on digital intraoral scanning compared to conventional impression-a split-mouth randomised clinical study. Clin Oral Investig 2019;23:4043-4050. doi: 10.1007/s00784019-02840-0.

14. Amornvit P, Sanohkan S. The accuracy of digital face scans obtained from 3D scanners: an in vitro study. Int J Environ Res Public Health 2019;16:5061. doi: 10.3390/ ijerph16245061. 